SHORT COMMMUNICATION Sokoto Journal of Veterinary Sciences

(P-ISSN 1595-093X/ E-ISSN 2315-6201)

Aliyu et al/Sokoto Journal of Veterinary Sciences (2016) 14(1): 39-44 http://dx.doi.org/10.4314/sokjvs.v14i1.7

\title{
Prevalence of potential toxigenic Aspergillus species isolated from poultry feeds in Sokoto metropolis
}

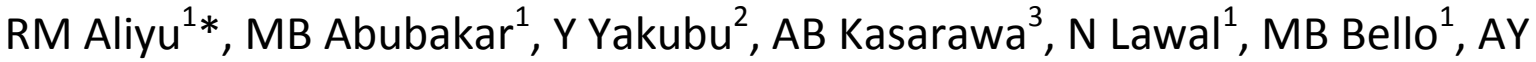 \\ Fardami $^{4}$ \\ 1. Department of Veterinary Microbiology, Faculty of Veterinary Medicine, Usmanu Danfodiyo \\ University, Sokoto, Nigeria. \\ 2. Department of Veterinary Public Health and Preventive Medicine, Faculty of Veterinary Medicine, \\ Usmanu Danfodiyo University, Sokoto, Nigeria. \\ 3. Department of Natural Sciences, Sokoto State Polytechnic, Sokoto, Nigeria. \\ 4. Department of Microbiology, Faculty of Science, Usmanu Danfodiyo University, Sokoto, Nigeria
}

*Correspondence: Tel.: +234 8032539564, E-mail: rabiuabdul2005@yahoo.com

\begin{abstract}
The objective of this study was to investigate the prevalence and risk factors of fungal organisms (especially Aspergillus species) in feeds used in poultry farms in Sokoto metropolis. During a period of 12 months (from April 2010 to March 2011), a total of 239 poultry feed samples comprising of 204 commercially prepared feeds and 35 self-compounded feeds were collected from 76 identified poultry farms in Sokoto and environs. Of the total 80 questionnaires administered, 76 (95.00\%) were responded to. Out of the total samples, fungal species were isolated from 198 (82.9\%) comprising of commercially prepared 163 (79.9\%) and self-compounded 35 (100.0\%) feed samples. A total of 258 fungal isolates were identified out of which 136 (52.7\%) were Aspergillus species. The most prevalent species were Aspergillus fumigatus 80 (58.8\%) followed by Aspergillus flavus 56 (41.2\%). Since Aspergillus species are among the leading mycotoxigenic fungi, this study reveals that a potential exists for the production of mycotoxins that may be of both veterinary public health significance and its attending economic losses.
\end{abstract}

Keywords: Aspergillus species, Mycotoxicosis, Poultry farms, Poultry feed, Sokoto metropolis

Received: 01-09- 2015

Accepted: 17-12-2015

\section{Introduction}

Evidences arising from epidemiological studies as well as from detailed experimental investigations have indicated that there is a strong relationship between certain feed ingredients and incidence of bacterial and fungal infections (Maciorowski et al., 2007; Obi \& Ozugbo, 2007; Miller, 1995). Mould and mycotoxin contamination of feed and feed ingredients occur worldwide and because of the ubiquitous nature of these microorganisms, they cannot be totally eliminated from feed ingredients (Trenholm et al., 1988).

Mould contamination is widespread in tropical countries where poultry production and processing are expanding rapidly (Okoli et al., 2006; Berghe et al., 1990). The contamination of agricultural commodities with toxigenic fungi under favourable conditions may lead to mycotoxin buildup reaching injurious levels for farm animals and human health. The production of mycotoxins has often been species-specific; therefore, identification of fungi is of prime importance, as they are among the most important contaminants of poultry feeds (Gentles et al., 1999). Aflatoxins are the most studied group of mycotoxins with clinical toxicosis, increase susceptibility to diseases and vaccination failures among others as the reported consequences in poultry (Gentles et al., 1999).

Animal feed may serve as a carrier for a wide variety of microorganisms. The primary mode of inoculation of feed materials is the transference of soil by the wind, rain, mechanical agitation, or insects to standing crops. Some of the microorganisms are adapted to the desiccated and relatively nutrient-deficient conditions of the soil and survive in similar niches on growing crops (Beuchat, 1978). In general, the amount of available water in the feed matrix determines 
whether a microorganism will grow or survive. Some microorganisms, primarily moulds, adapt to the low amount of available moisture and grow actively within stored seeds and grains. Others will enter a survival state (such as spore formation) until the moisture is high enough for bacterial activity (Maciorowski et al., 2007).

There are numerous ways contaminating mycoflora can negatively affect feed quality; these include a reduction in feed nutrients and dry matter, musty or sour odours, feed caking and mycotoxin production. Finally, the feed can act as a carrier for animal and human pathogens. The type of feed, processing treatments and storage conditions can all be factors that influence the levels and types of microorganisms present (Maciorowski et al., 2007).

Regular monitoring of the toxigenic mycoflora of feeds and foods are a pre-requisite for the development of strategies to control or prevent mycotoxins exposure of animal feed and human population. Study of the prevalence of toxigenic mycobiota of the animals/poultry feeds is regularly and frequently reported from many countries, including Argentina (Dalcero et al., 1997), Spain (Accensi et al., 2004), Brazil (Oliveira et al., 2006), Pakistan (Hanif et al., 2006; lqbal et al., 2006; Russell \& Peterson, 2007; Saleemi et al., 2010) and Iran (Azarakhsh et al., 2011).

In Nigeria however, Osho et al. (2007) reported the isolation of Aspergillus sp. and Rhizopus sp. in poultry feed in the southwestern region of Nigeria. Similarly, in a survey of fungal contamination in commercial poultry feed in the southern state of Nigeria (Oyejide et al., 1987), reported that 57$62 \%$ of the chick and broiler starter, grower, broiler finishers and layer's rations were contaminated with Aflatoxin. Uwaezuoke \& Ogbulie (2008) in Owerri, Imo state and Obi \& Ozugbo (2007) in Umuahia, Abia State; independently reported the isolation of pathogenic bacteria and fungi genera in the poultry feed samples sold in parts of eastern Nigeria. This is an indication that no feed was found completely free from fungal contamination. The production of poultry feeds for local and commercial farmers in the developing countries (including Nigeria) requires an above average microbiological safety regulation to escape the microbial contamination of the product (Obi \& Ozugbo, 2007). Thus, the present study is aimed at investigating the prevalence of Aspergillus $s p$. contamination of poultry feeds used in poultry farms in Sokoto metropolis.

\section{Materials and Methods}

Study area

The study area was Sokoto metropolis, the capital of Sokoto State, Nigeria. The area comprises Sokoto north, Sokoto South, some parts of DangeShuni and Wamakko local government areas. Each of the local government has an average of 11 wards. The state is located at latitude $13^{\circ} \mathrm{N}$ and between longitudes $4^{0} 8^{\prime} \mathrm{E}$ and $6^{\circ} 54^{\prime} \mathrm{E}$ in the extreme North Western part of Nigeria, covering an area of approximately 56,000 square kilometres (Roger, 1999). The state shares border with the Niger Republic to the north, Kebbi State to the south and Zamfara State to the east. Based on the 2006 population census, It has a projected population of about 4,244,399 as of 2009 (National Population Commission, 2006). The state is ranked second in livestock population with an average 3 million cattle, 4 million goats, 3.85 million sheep, 0.8 million camels and a million Poultry (SSIPC, 2008).

\section{Study design}

The study is a cross-sectional Study that covered a period of 12 months (April 2010 to March 2011). It involved microbiological analysis of poultry feeds from $76(95 \%)$ of the identified 80 poultry farms located in the area of study.

The Study was designed as follows;

1. Questionnaire survey:

Eighty (80) closed-ended structured Questionnaires were designed and administered to farm managers on the spot in the study area. The questionnaire was designed to provide information on the flock size; type of poultry kept and feeds management especially with regard to storage of feeds.

2. Microbiological analysis of poultry feeds for fungal organisms.

The sample size was calculated, based on an estimated prevalence rate of $83.3 \%$ (Saleemi et al., 2010) at the $95 \%$ level of confidence. A minimum sample size of 214 was obtained.

\section{Samples collection}

During sampling visits of the 76 participating farms, a total of 239 poultry feed samples comprising of commercially prepared feed $(n=204)$ and self-compounded feed $(n=35)$ were collected. From each visited farm, feed present in the farm was sampled by selecting $20-25 \%$ of the bags present in the farm by simple random sampling. For each sample, 5-10 grams of feed were collected in a polythene bag and then collectively transported to the Veterinary Microbiology laboratory for immediate processing. In some cases, the feed samples were stored at room temperature $\left(22-25^{\circ} \mathrm{C}\right)$ for a maximum of 24 hours prior to inoculation onto culture media. 
Isolation and identification of fungi

Isolation of the fungi from the feed samples obtained were carried out using Sabouraud dextrose agar (S.D.A) (CM 0041: Oxoid ' Ltd, UK) supplemented with chloramphenicol at $40 \mu \mathrm{g} / \mathrm{ml}$ and gentamycin at $500 \mu \mathrm{g} / \mathrm{ml}$ (Davis et al., 1980) and prepared according to the manufacturer's instructions. One gram of the feed sample was aseptically transferred to a sterile test tube and 9 millilitres of sterile distilled water was added to the feed and thoroughly mixed to perform a tenfold serial dilution of the sample, $0.1 \mathrm{ml}$ of the dilution was cultured by a spread plate technique using a sterile bent glass rod and then incubated at room temperature $\left(22-25^{\circ} \mathrm{C}\right)$ for 5-14 days. The fungal isolates were identified to the genus/species level based on macroscopic and microscopic characteristics of the isolates obtained from pure cultures. Such characteristics include; rapidity of growth, colour of obverse and reverse site of the culture plate, shape, texture and consistency of the growth, septation of hyphae, shape, size, texture and arrangement of the conidia, according to the methods of Ogbulie et al. (1998); Carter \& Cole (1990) and Barnett \& Hunter (1998). Wet mount smears of pure cultured colonies were stained with lactophenol cotton blue stain. Identification of Aspergillus species was made based on macroscopic and microscopic features in accordance with the standard guidelines Barnett \& Hunter (1998), Carter \& Cole (1990) and Raper \& Fennell (1965). The fungal isolates were also sub-cultured onto SDA slants, incubated at $27^{\circ} \mathrm{C}$ for 10 days and stored in a refrigerator for future studies (Saleemi et al., 2010).

\section{Statistical analysis}

The data generated were presented in the form of Tables and Figures using frequenc distribution. Data was analysed using descriptyive statistics.

\section{Results and Discussion}

Out of the total of 80 poultry farms identified and administered with questionnaires, $76(95.0 \%)$ gave their consent and were included in the study. Out of the 76 respondents, $8(10.5 \%)$ had a poultry size of $\geq 1000$ birds, $6(7.9 \%) \geq 500,13(17.1 \%) \geq 200$ and 49 (64.5\%) kept less than 200 birds.

The results of the study revealed that 53 (69.7\%) used commercially prepared feeds while 23 (30.3\%) of the farmers compounded their feeds. The study further shows that 52 (68.4\%) of the respondents kept their feed in a room used as a store while 18 (23.7\%) kept the feeds within the poultry pen and 6 (7.9\%) used open space (Table 1). The growth of the moulds was observed in $44(57.9 \%)$ of the farms with subsequent caking of the affected feeds.

The mycological survey of 239 samples of poultry feed from Sokoto metropolis showed the presence of potentially toxigenic and infective Aspergillus species (Plate 1). Of the total 239 feed samples analysed for the presence of fungal organisms, 198 $(82.8 \%)$ revealed the presence of fungal organisms with Aspergillus spp. having the highest isolation rate of 136 (52.71\%) while all the remaining 4 fungal species (Penicillium spp., Fusarium spp., Mucor spp. and Rhizopus spp..) account for 122 (47.29\%) (Figure 1). Similarly, of the 136 Aspergillus species, 80 (58.8\%) was Aspergillus fumigatus, and 56 (41.2\%) was Aspergillus flavus (Table 2).

Table 1: Methods of feed storage practiced by poultry farmers in Sokoto metropolis with isolated fungal species

\begin{tabular}{lccccc}
\hline $\begin{array}{l}\text { Methods } \\
\text { of storage }\end{array}$ & $\begin{array}{c}\text { Number of } \\
\text { farms (\%) }\end{array}$ & $\begin{array}{c}\text { Aspergillus } \\
\text { fumigatus (\%) }\end{array}$ & $\begin{array}{c}\text { Aspergillus } \\
\text { flavus (\%) }\end{array}$ & $\begin{array}{c}\text { Other fungal } \\
\text { agents }\end{array}$ & Total (\%) \\
\hline Store (Room) & $52(68.4)$ & $38(47.5)$ & $26(46.4)$ & $59(48.4)$ & $123(47.7)$ \\
Poultry pen & $18(23.7)$ & $32(40.0)$ & $24(42.9)$ & $52(42.6)$ & $108(41.9)$ \\
Open space & $06(07.9)$ & $10(12.5)$ & $06(10.7)$ & $11(09.0)$ & $27(10.5)$ \\
\hline Total & $76(100.0)$ & $80(100.0 \%)$ & $56(100.0 \%)$ & $122(100.0 \%)$ & $258(100.0)$ \\
\hline
\end{tabular}

Table 2: The occurrence of Aspergillus species isolated from poultry feed in Sokoto metropolis

\begin{tabular}{lccc}
\hline Aspergillus spp. & Commercially prepared & Self-compounded & Total (\%) \\
\hline Aspergillus fumigatus & $77(68.1 \%)$ & $3(13.0 \%)$ & $80(58.8)$ \\
Aspergillus flavus & $36(32.9 \%)$ & $20(87.0 \%)$ & $56(41.2)$ \\
\hline Total & $113(100.0 \%)$ & $23(100.0 \%)$ & $136(100.0)$ \\
\hline
\end{tabular}



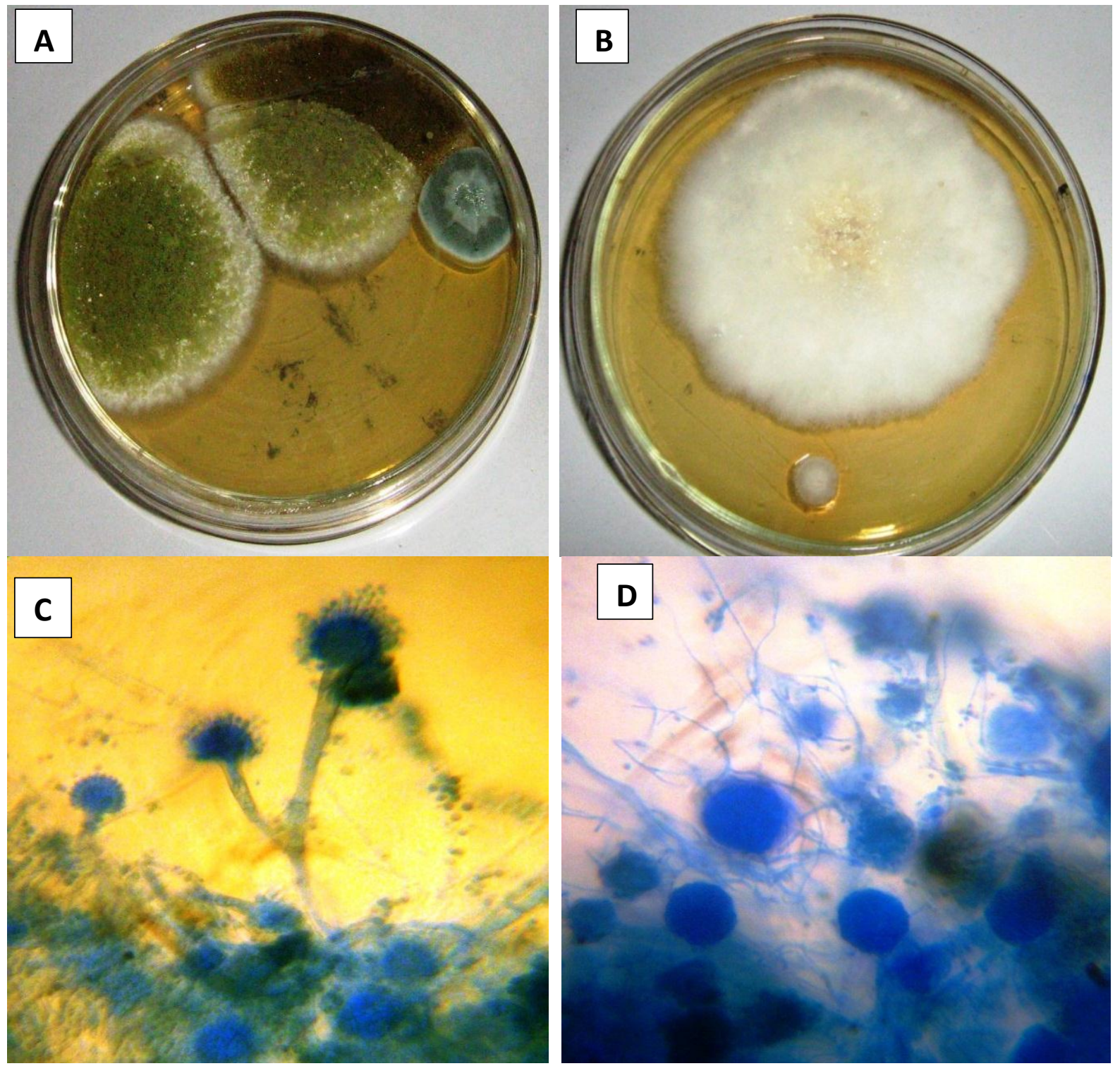

Plate 1: Macro and micromorphology of fungal species isolated from poultry feed in the poultry farms in Sokoto metropolis. Primary isolates showing mixed fungal agents (A), a pure fungal isolate (B), Aspergillus fumigatus (C) Aspergillus flavus (D).

Based on the findings from this study, the majority $(64.47 \%)$ of the farmers in the study area kept less than 200 birds, this probably explain why higher proportion of the farmers (69.74\%) purchased commercially prepared feeds (Vita feeds ${ }^{\circledR}$ ) and also used the business as a supplement of their income whereas $30.26 \%$ compounded their feed themselves so as to maximize profit.

About fifty-eight percent of the respondents $(57.89 \%)$ indicated mould growth on the poultry feed with subsequent caking. This may not be unconnected with the type of feed management, especially with regards to storage because 18 $(23.68 \%)$ of the respondents said they kept their feed within the poultry pen whilst 6 (7.89\%) kept theirs in an open space. This method of storage

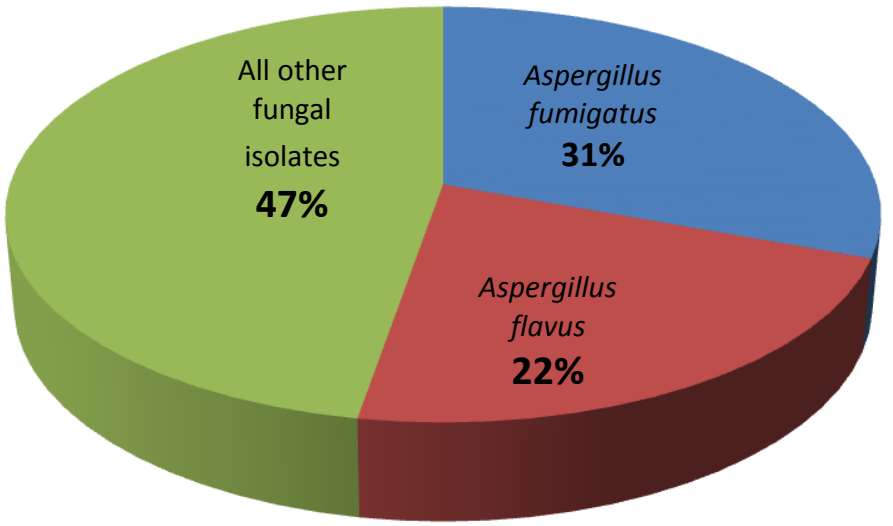

Figure 1: Distribution trend of fungi in poultry feed samples collected from Sokoto and its environs 
increases the water activity of the feed due to exposure to the atmospheric humidity and therefore, encourages the growth of contaminating fungi and bacteria in the feed which may also explain the higher isolation rates of the fungi in all the types of feed sampled in this study. In the study area, fungal contaminations were present in a high proportion (82.8\%) of the feed samples, this finding is in agreement with similar studies in Nigeria (Uwaezuoke \& Ogbulie, 2008; Obi \& Ozugbo, 2007; Osho et al., 2007). The report further supported the findings from other regions of the world, including Serbia (Krnjaja et al., 2007), Brazil (Oliveira et al., 2006; Rosa et al., 2006), Argentina (Dalcero et al., 1997) and Pakistan (Saleemi et al., 2010).

Similarly, high-frequency isolations of Aspergillus spp. and Penicillium spp. from mixed poultry feeds have been reported in Spain (Bragulat et al., 1995; Abarca et al., 1994), Brazil (Simas et al., 2007), Argentina (Oliveira et al., 2006), Pakistan (Saleemi et al., 2010) and Nigeria (Uwaezuoke \& Ogbulie, 2008; Obi \& Ozugbo, 2007).

\section{References}

Abarca ML, Bragulat MR, Castellá G \& Cabañes FJ (1994). A Research Note: Mycoflora and Aflatoxin-Producing Strains in Animal Mixed Feeds. Journal of Food Protection, 57(3): 184-266.

Accensi F, Abarca ML \& Cabañes FJ (2004). Occurrence of Aspergillus species in mixed feeds and component raw materials and their ability to produce ochratoxin A. Food Microbiology, 21(5): 623-627.

Azarakhsh Y, Sabokbar A \& Bayat M (2011). Incidence of the Most Common Toxigenic Aspergillus Species in Broiler Feeds in Kermanshah Province, West of Iran. Global Veterinaria, 6(1): 73-77.

Barnett HL \& Hunter BB (1998). Illustrated Genera of Imperfect Fungi, fourth edition, Minn. Minneapolis Burgnees Publishing Company. Minneapolis M. N. Pp 241.

Battilani P, Pietri A, Bertuzzi T, Languasco L, Giorni $P$ \& Kozakiewicz Z (2003). Occurrence of ochratoxin A-producing fungi in grapes grown in Italy. Journal of Food Protection, 66(4): 633-636.

Berghe $\mathrm{CH}$, van den Ahouangninou PO \& Deka EK (1990). The effect of antioxidant and mould inhibitor on feed quality and the performance of broilers under tropical conditions. Tropical Science, 30(1): 5-13.

Beuchat L (1978). Microbial alterations of grains, legumes, and oilseeds. Food Technology, 32(5): 193-198.
High contamination level of Aspergillus spp. might be due to their high-temperature tolerance (Battilani et al., 2003), which might also have been responsible for the high frequency of Aspergillus spp. in poultry feeds in the present study.

In the present study, the main contaminating fungus was $A$. fumigatus followed by $A$. flavus, known aflatoxigenic species. It could be stated that Aspergillus spp., Penicillium spp. and Fusarium spp. was the typical fungal genera contaminating poultry feeds. In fact, they are very important contaminants being renowned for their ability to form a huge number of various types of mycotoxins. These species occurring worldwide are the main contaminants of stored cereals and feeds, including the production of toxicologically significant mycotoxins. Based on the result of this study, it is recommended that Poultry feeds should be stored in a dry atmospheric environment to prevent the development of potentially toxigenic moulds and further research needs to be done on the amount and type of mycotoxins present in the poultry feeds in the study area.

Bragulat MR, Abarca ML, Castellá G \& Cabañes FJ (1995). A mycological survey on mixed poultry feeds and mixed rabbit feeds. Journal of the Science of Food and Agriculture, 67(2): 215-220.

Carter GR \& Cole JR (1990). Diagnostic Procedure in Veterinary Bacteriology and Mycology, fifth edition. Academic Press Inc. Pp 372373.

Dalcero A, Magnoli C, Chiacchiera S, Palacios G \& Reynoso M (1997). Mycoflora and incidence of aflatoxin B1, zearalenone and deoxynivalenol in poultry feeds in Argentina. Mycopathologia, 137(3): 17984.

Davis BD, Dulbecco R, Eisen HN \& Ginsberg HS (1980). Microbiology Including Immunology and Molecular Genetics, third edition, Harper International Edition. Pp 832.

Gentles A, Smith EE, Kubena LF, Duffus E, Johnson $P$, Thompson J, Harvey RB \& Edrington T.S. (1999). Toxicological evaluations of cyclopiazonic acid and ochratoxin $A$ in broilers. Poultry Science, 78(10): 13801384.

Hanif NQ, Naseem M, Khatoon S \& Malik N (2006). Prevalence of mycotoxins in poultry rations. Pakistan Journal of Scientific and Industrial Research, 49(2): 120-124.

Iqbal A, Khalil IA \& Shah H (2006). Aflatoxin contents of stored and artificially 
inoculated cereals and nuts. Food Chemistry, 98(4): 699-703.

Krnjaja V, Lević J, Tomić Z, Nešić Z, Stojanović L \& Trenkovski S (2007). Dynamics of incidence and frequency of populations of Fusarium species on stored maize grain. Biotechnology in Animal Husbandry, 23(56): 589-600.

Maciorowski KG, Herrera P, Jones FT, Pillai SD \& Ricke SC (2007). Effects on poultry and livestock of feed contamination with bacteria and fungi. Animal Feed Science and Technology, 133(1-2): 109-136.

Miller JD (1995). Fungi and mycotoxins in grain: Implications for stored product research. Journal of Stored Products Research, 31(1): 1-16.

National Population Commission (NPC), Nigeria. (2006). Report on final 2006 census result. Abuja: National Population Commission of Nigeria; Abuja, Nigeria. Preliminary Report. Pp 1-2.

Obi CN \& Ozugbo IJ (2007). Microbiological analysis of poultry Feeds sold in Umuahia main market, Abia State, Nigeria. Research Journal of Applied Sciences, 2(1): 22-25.

Ogbulie JN, Uwaezuoke JC \& Ogiehor ST (1998). Introductory Microbiology Practical, Springfield Publishers, Owerri. Pp 162.

Okoli IC, Nweke CU, Okoli CG \& Opara MN (2006). Assessment of the mycoflora of commercial poultry feeds sold in the humid tropical environment of Imo State, Nigeria. International Journal of Environmental Science \& Technology, 3(1): 9-14.

Oliveira GR, Ribeiro JM, Fraga ME, Cavaglieri LR, Direito GM, Keller KM, Dalcero AM \& Rosa CA (2006). Mycobiota in poultry feeds and natural occurrence of aflatoxins, fumonisins and zearalenone in the Rio de Janeiro State, Brazil. Mycopathologia, 162(5): 355-362.

Osho IB, Awoniyi TAM \& Adebayo Al (2007). Mycological investigation of compounded poultry feeds used in poultry farms in southwest Nigeria. African Journal of Biotechnology, 6(15): 1837-1839.
Oyejide A, Tewe OO \& Okosum SE (1987). Prevalence of aflatoxin B1 in commercial poultry rations in Nigeria. Beiträge zur Tropischen Landwirtschaft und Veterinärmedizin, 25(3): 337-341.

Raper KB \& Fennell DI (1965). The Genus Aspergillus: Baltimore. Williams \& Wilkins Co., Pp 681-686.

Roger B (1999). Traditional Livestock Breeds: Physical Distribution and Dynamics in Relation to Ecology of West Africa., 122: London. SW1E, 5DP. Pp 1-69.

Rosa CAR, Ribeiro JMM, Fraga MJ, Gatti $M$, Cavaglieri LR, Magnoli CE, Dalcero AM \& Lopes CWG (2006). Mycoflora of poultry feeds and ochratoxin-producing ability of isolated Aspergillus and Penicillium species. Veterinary Microbiology, 113(1-2): 89-96.

Russell R \& Peterson M (2007). Aflatoxin contamination in chilli from Pakistan. Food Control, 18(7): 817-820.

Saleemi MK, Khan MZ, Khan A \& Javed I (2010). Mycoflora of poultry feeds and mycotoxins producing potential of Aspergillus species. Pakistan Journal of Botany, 42(1): 427434.

Simas MMS, Botura $M B$, Correa $B$, Sabino $M$, Mallmann CA, Bitencourt TCBSC \& Batatinha MJM (2007). Determination of fungal microbiota and mycotoxins in brewers grain used in dairy cattle feeding in the state of Bahia, Brazil. Food Control, 18(5): 404-408.

SSIPC (2008). Beef up Your Profits by Investing in Sokoto State's Livestock Sector: Sokoto, Pp 1-8.

Trenholm HL, Prelusky DB, JC Y \& Miller JD (1988). Reducing Mycotoxins in Animal Feeds: Ottawa 1827E, P 11.

Uwaezuoke J \& Ogbulie J (2008). Microbiological quality of commercially available poultry feeds sold in parts of Eastern Nigeria. Journal of Applied Sciences and Environmental Management, 12(1): 113117. 